УдК 343.21

\title{
I. I. Koгymuч
}

\section{СУТНІСТЬ І СТРУКТУРА ОКРЕМИХ СКЛАДНИКІВ МЕТОДИКИ СУДОВОГО РОЗГЛЯДУ КРИМІНАЛЬНИХ СПРАВ}

Постановка проблеми. Останніми роками науковці працюють над змінами у предметі криміналістичної методики. Серед розробників цієї тематики виправдано розглядати, зокрема, В.П. Бахіна [1], Р.С. Бєлкіна [2; 3], О.М. Васильєва [4], І.О. Возгріна [5], В.Г. Гончаренка [6], В.Ю. Шепітька [7], А.Ф. Волобуєва [8], В.О. Гавло [9], І.Ф. Герасимова [10], С.О. Голунського [11], В.А. Журавля [12], А.В. Іщенка [13], В.П. Корж [14, 15], Г.А. Матусовського [16], В.В. Тіщенка [17], Б.В. Щура [18] та ін. Відомо й те, що не в останню чергу цей інтерес породжений потребою дослідження та розробки прийомів і засобів не лише досудового розслідування, а також судового розгляду кримінальних справ. Саме тому предметом криміналістичної методики все більше охоплені і криміналістичні закономірності цієї стадії кримінального процесу [19; 20].

Виклад основного матеріалу дослідження. Судовий розгляд кожної кримінальної справи є індивідуальним. Цю індивідуальність забезпечує, з одного боку, матеріально-правовий склад досліджуваного безпосередньо в суді кримінального правопорушення, з іншого - властивий лише цьому окремому дослідженню його хід. Однак безспірно й те, що кримінальним правопорушенням (злочинам, проступкам), процесу їхнього розслідування та судового розгляду поряд з індивідуальним властиве і щось спільне (типове), закономірне. У найзагальнішому варіанті викладу цими закономірностями судового розгляду можна вважати:

1) закономірності у діяльності обвинувача - прокурора, захисника професійного адвоката, головуючого - професійного судді під час вивчення кожним із них у розрізі специфіки виконуваної професійної функції (обвинувачення, захисту, вирішення кримінальної справи) матеріалів кримінальної справи на предмет перевірки наявної (чи відсутньої) там інформації про подію (події), що містять ознаки злочинів. Адже це вивчення здійснюється не хаотично, а системно, за певною типовою схемою (алгоритмом), що вже стало загальноприйнятним (закономірним) у їхній діяльності на цьому відрізку судового слухання справи. Якщо коротко - це закономірності форми підготовки; 
2) закономірності встановлення обставин, що підлягають встановленню і доказуванню під час судового розгляду кримінальних справах (закономірності змісту підготовки);

3) закономірності напрацювання зумовлених судовими ситуаціями типових програм (алгоритмів) судових дій слідчого характеру (надалі для зручності назвемо ї судово-слідчими діями) та інших передбачених законодавством заходів для встановлення істини у кримінальних справах (судово-контрольні та організаційно-забезпечувальні дії суду), тобто закономірності вибору інструментарію;

4) закономірності безпосереднього виконання судово-слідчих дій та інших заходів під час судового розгляду кримінальних справ (закономірності реалізації інструментарію) та ін.

Отже, враховуючи закономірності, властиві стадії досудового розслідування (про що знаємо з вивчення криміналістики), і щойно у загальному вигляді наведені закономірності стадії судового провадження, криміналістична методика як розділ цієї науки логічно мала б містити: 1) методику розслідування злочинів; 2) методику судового розгляду кримінальних справ.

У функціонально-часовому аспекті положення методики розслідування злочинів $є$ предметними з моменту відкриття кримінального провадження і до його завершення у будь-якій формі, передбаченій ст. 283 КПК України (закриття кримінального провадження; звернення до суду з клопотанням про звільнення особи від кримінальної відповідальності; звернення до суду з обвинувальним актом, клопотанням про застосування примусових заходів медичного або виховного характеру тощо). Стосовно положень методики судового розгляду кримінальних справ, то вони є актуальними з моменту надходження матеріалів кримінального провадження у суд і до прийняття ним у ній відповідного процесуального рішення (вироку, ухвали).

Безумовно, чимало з методичних рекомендацій досудового провадження зберігають свою значущість і в комплексі криміналістичного забезпечення судового розгляду. Однак унаслідок суттєвих відмінностей між цими стадіями кримінального провадження у методиці судового розгляду все ж, як правило, досліджують та шукають відповіді на запитання, які багато в чому є іншими, аніж як для методики розслідування певних видів (груп) злочинів. Це, зокрема, відповіді на такі запитання: 1) як підготувати (організувати та спланувати) судовий розгляд кримінальної справи (залежно, по-перше, від так званої періодизації цього розгляду - чи це підготовче провадження, початок судового розгляду, дослідний його етап, судові дебати; по-друге, від правового статусу та призначення самого суб'єкта планування - уже згадуваних прокурора - обвинувача, захисника - професійного адвоката, головуючого - професійного судді, діяльність яких зумовлена специфікою властивої кожному з них процесуальної функції); 2) яка сутність і види судових ситуацій, а також чинників формування (виникнення) цих ситуацій та можливість ї прогнозування вищеназваними учасниками судового провадження; 3) як впливають судові ситуації на виокремлення вищеназваними суб'єктами завдань цієї стадії провадження, їхній зміст і 
види; 4) як ці завдання екстраполюються в алгоритм дій суду, прокурора обвинувача та захисника (яким має бути типовий набір судово-слідчих та інших процесуальних дій, їх комплексів); 5) якою повинна бути залежно від можливих різнорівневих судових ситуацій тактика виконання цих дій та комплексів тощо. Адже аналогічно ситуативності тактики досудового розслідування тактика судового розгляду також $є$ ситуативною, як і будьяка інша пошуково-дослідна діяльність.

Різнорівневість судової ситуації - це рівень ситуації усього судового розгляду (найвищий), рівень ситуації етапу судового провадження (вищий), рівень ситуації проведення конкретної судової (судово-слідчої) дії (чи їх поєднання - операції) (середній), рівень ситуації застосування будь-якого тактичного засобу (чи їх поєднання - тактичного прийому, тактичної комбінації).

Однак є ще одна суттєва ознака стадії судового провадження. Саме тут у контексті дотримання засад кримінального провадження у найповнішому обсязі реалізують уже згадувані процесуальні функції обвинувачення, захисту та кримінальної юстиції. Специфіка закономірностей та особливості діяльності учасників кримінального провадження - безпосередніх реалізаторів цих функцій (прокурора, адвоката, судді) зумовлює відповідну специфічність диференційованих за цією ознакою криміналістичних рекомендацій цим суб’єктам.

Іншими словами, криміналістика повинна містити арсенал порад як для прокурора, так і для адвоката, суду. Цей арсенал у вигляді теоретичних положень і розроблених на їх основі рекомендацій має бути об'єднаний забезпеченням єдиної і спільної мети кримінального провадження (встановити об'єктивну істину, або ж, переслідуючи законний інтерес, сприяти цьому встановленню істини). Тому є всі підстави вести мову про три взаємопов'язані складники методики судового розгляду кримінальних справ у такій пріоритетно (як для науки криміналістики) зумовленій ієрархії: 1) методику підтримання прокурором публічного обвинувачення; 2) методику професійного захисту; 3) методику суду у вирішенні справи.

Отже, у наукознавчому контексті виправдано вважати, що методика судового розгляду кримінальних справ - це складова частина криміналістичної методики, яка містить систему наукових положень і напрацьованих на їхній основі та відповідно до вимог закону рекомендацій щодо раціональної підготовки і здійснення судового провадження в окремих категоріях кримінальних справ професійними суб'єктами цієї діяльності (суддею (суддями), прокурором - обвинувачем, адвокатом - захисником) [21, с. 62].

Окрім того, методика судового розгляду кримінальних справ передбачає й інший аспект - безпосередній процес розгляду кримінальних справ у суді першої інстанції, тобто специфічну діяльність уповноважених законом органів та осіб, яку здійснюють на підставі застосування засобів криміналістичної техніки, прийомів криміналістичної тактики, системи методичних рекомендацій щодо судового розгляду кримінальних справ про певні види (групи) суспільно-небезпечних діянь. Саме у взаємозв'язку цих двох 
напрямів - практичного і теоретичного - криміналістична методика судового розгляду кримінальних справ виявляє, як видається, своє призначення, сприяючи розробці наукових рекомендацій здійснення цього процесу і запровадження їх у практику кримінальних проваджень.

Поняття методики судового розгляду кримінальних справ необхідне, зокрема, для об’єднання у єдину й чітку систему багатьох криміналістичних рекомендацій. Крім того, це матиме практичне значення для використання цих рекомендацій судом, прокурором - обвинувачем та адвокатом - захисником у ході розгляду кримінальних справ.

Методика судового розгляду повинна містити науково-практичні рекомендації із формування системи судово-слідчих, організаційно-підготовчих та інших судових дій. Цільове призначення цього складника криміналістичної методики полягає в упорядкуванні використання різних криміналістичних засобів та методів для вирішення завдань кримінального провадження шляхом максимальної оптимізації процесу судового розгляду кримінальних справ.

Враховуючи види та характер уже частково згаданих закономірностей, що є предметом методики судового розгляду кримінальних справ, можна запропонувати двохелементну ї систему.

1. Загальні положення методики судового розгляду кримінальних справ, утворених теоретичними основами методики: ï предметом, метою і завданнями, системою; історією і джерелами утворення; співвідношенням з іншими складниками криміналістичної методики; загальними правилами (вимогами) побудови й основними положеннями методик судового розгляду кримінальних справ із диференціюванням їх за певними категоріями справ (щодо видів чи груп злочинів) та за головними суб'єктами судового розгляду (суду, прокурора - обвинувача, адвоката - захисника) тощо. Крім теоретичного значення, загальна частина має також і практичне значення, оскільки саме від того, наскільки науково обгрунтованими є іiі загальні положення як складники загальних положень криміналістичної методики, залежить ефективність розробки і використання на практиці типових методик судового розгляду певних категорій кримінальних справ.

Структура (зміст) загальних положень повинна мати такий вигляд: поняття і сутність, об'єкти методики як складової частини розділу криміналістичної методики; базові вимоги (критерії) щодо побудови методик судового розгляду кримінальних справ, які стосуються певних видів (груп) злочинів; джерела методики судового розгляду кримінальних справ; завдання криміналістичної методики судового розгляду кримінальних справ і їі зв'язки з іншими складниками криміналістики; система методики судового розгляду кримінальних справ, іiі структурні елементи; поняття, класифікація і структура типових методик судового розгляду кримінальних справ; роль криміналістичних характеристик злочинів відповідних видів (груп) та інформаціі зі справи про особливості процесу дослідження події злочину на досудових стадіях кримінального провадження у створенні та змісті типових методик. Від якості розробки цих питань залежить створення 
ефективних типових методик та успіх їх застосування у вирішенні судом кримінальних справ.

2. Типові методики судового розгляду кримінальних справ певних категорій: науково обгрунтовані системи методичних рекомендацій для суду, прокурора - обвинувача й адвоката - захисника з підготовки та безпосереднього здійснення чи участі у здійсненні ними судового розгляду кримінальних справ щодо окремих видів (груп) злочинів.

Рекомендації, напрацьовані в рамках видових (групових) методик, стосуються вивчення, узагальнення слідчої та судової практики, виокремлення найтиповіших і таких, що найчастіше повторюються, судових ситуацій, які трапляються у багатьох чи в усіх категоріях справ. Для судового розгляду кримінальних справ найхарактернішими і такими, що нагально вимагають напрацювання криміналістичних рекомендацій, є ситуації, 3 якими найчастіше і найпроблемніше доводиться працювати практикам: необхідність заповнення у суді прогалин досудового розслідування; наявність неусунених протиріч у доказовому матеріалі; дослідження доказів, які суттєво змінилися під час судового розгляду порівняно з досудовим розслідуванням, тощо.

Необхідно, на нашу думку, щоб кожна типова методика містила рекомендації пошуку відповідей принаймні на такі запитання: а) що потрібно встановлювати у конкретній категорії справ; яке коло обставин підлягає встановленню (доказуванню), виходячи із КПК України, положень кримінально-правової, криміналістичної, кримінологічної та психологічної характеристик відповідного роду, виду чи підвиду злочинів; б) як, яким шляхом, за допомогою яких (зокрема, судово-процесуальних) дій з'ясовуватимуть зазначені обставини (це значною мірою залежить від судової ситуації, що формується у справі, найпоширеніші з яких (типові) також повинні знайти відображення у відповідній методиці); в) у якій послідовності необхідно виконувати згадані судові та судово-слідчі діiі; як тактично і за допомогою яких технічних засобів їх здійснюватимуть; г) як передбачувані результати дослідження доказів впливатимуть на формування позиції кожної з них і використовуватимуться у судових дебатах (це важливо для сторін, що беруть участь у справі, насамперед - обвинувачення і захисту).

У такий спосіб типова структура методики судового розгляду певної категорії кримінальних справ може набувати такого вигляду: криміналістична характеристика (злочинів відповідних видів чи груп) та характеристика інформації зі справи, предмет судового розгляду (обставини, що підлягають встановленню судовим розглядом), судові ситуації, система судових і судово-слідчих дій залежно від категорії кримінальної справи (справ), особливості тактики судово-слідчих дій щодо окремих категорій кримінальних справ, тактичні особливості судових дебатів, використання у суді спеціальних знань залежно від специфіки (категорії) кримінальної справи, особливості тактики ухвалення (постановлення) судового рішення тощо.

Криміналістична характеристика правопорушення (зокрема, злочину) традиційно мала б бути одним із важливих структурних елементів типової 
методики судового розгляду певної категорії кримінальних справ. Адже використання криміналістичної характеристики відповідного виду злочину у підготовці та здійсненні стосовно нього судового розгляду має певні особливості порівняно з досудовим розслідуванням.

Слідчий для виконання завдань досудового розслідування конкретного злочину користується узагальненою науковою інформацією про типові відомості щодо тих чи інших елементів цього ж виду злочину. У ході підготовки, як і самого судового розгляду, прокурор, адвокат і суддя також використовують ці теоретичні криміналістичні знання (криміналістичну характеристику злочину чи групи злочинів). Однак, крім цього, всім цим учасникам судового провадження із позиції вищезазначеної загальної інформаційної моделі стосовно певного злочину (злочинів), необхідно ще й оцінити правильність дій відповідних суб’єктів (зокрема, слідчого, прокурора - процесуального керівника, адвоката - захисника) на стадії досудового розслідування у провадженні та обгрунтованість їхніх рішень (висновків).

Саме тому типова методика судового розгляду певної категорії кримінальних справ повинна, якщо розглядати цю інституцію винятково в контексті науки криміналістики, грунтуватись, на нашу думку, на двох складниках цього елементу методики: 1) на криміналістичній характеристиці злочину відповідного виду чи групи; 2) на типовій характеристиці процесу і результатів досудового розслідування злочину відповідного виду (групи).

Іншими словами, першим складником є криміналістична характеристика злочину відповідного виду чи групи (аналогічно як в окремих чи групових методиках розслідування), тобто заснована на практиці правоохоронних органів та криміналістичних досліджень модель системи зведених (узагальнених) теоретичних відомостей про криміналістично значущі ознаки виду, групи або конкретного злочину, яка має на меті оптимізувати процес виявлення і розслідування таких діянь. Другий складник - це криміналістична характеристика інформації зі справи про найпоширені (типові) особливості процесу дослідження події відповідного виду (групи) злочинів на досудових стадіях кримінального провадження (криміналістична характеристика досудового розслідування виду (групи) злочинів).

Прокурор - обвинувач, адвокат - захисник, суддя (судді), знаючи цю науково узагальнену інформаційну модель про особливості досудового розслідування таких кримінальних правопорушень, правильно формують уявлення про якість реально виконаного розслідування у конкретному кримінальному провадженні, стосовно якого згодом прокурор підтримуватиме обвинувачення, адвокат - здійснюватиме захист, суддя (судді) - вирішуватимуть кримінальну справу.

Іншими словами, ця підсистема (аспект) криміналістичної характеристики слугує узгодженою множиною взаємозв'язаних елементів, найважливішим серед яких є узагальнена інформація (інформаційна модель) про: 1) типові форми і методи криміналістичного пізнання на стадії досудового розслідування; 2) особливості так званої криміналістичної діяльності 
головних учасників кримінального провадження, зокрема закономірності психічного і фізичного функціонування у розслідуванні злочину слідчого i наглядаючого прокурора - процесуального керівника розслідування, а також у захисній діяльності на стадії досудового розслідування адвоката - захисника підозрюваного; 3) особливості досудового провадження, що породжують недоліки розслідування та професійного захисту у вигляді слідчих, прокурорських та адвокатських помилок і прогалин, а також причини, що їх породжують, та умови, які цьому сприяють.

Щодо форм криміналістичного пізнання зазначимо, що таких є дві: процесуальна і криміналістична. Процесуальна форма - це спосіб реалізації норм кримінального процесуального законодавства. Вона, як відомо, не торкається характеру та виду засобів і прийомів, якими здійснюється пізнання.

Так, законодавець не регламентує тактику дій слідчого чи адвоката - захисника під час провадження (наприклад, допиту); не приписує, як, у якій послідовності їм належить ставити запитання, які застосовувати прийоми впливу і технічні засоби, щоб одержати і зафіксувати показання особи, яка допитується. Цей змістовний аспект пізнавальної діяльності розкриває (мала б розкривати) наука криміналістика. Адже саме вона покликана розробляти тактичні прийоми і технічні засоби діяльності слідчого, частково - адвоката під час провадження конкретної слідчої (розшукової) дії. У цьому якраз і полягає друга форма пізнання - власне криміналістична.

Методи криміналістичного пізнання - це всім нам відомі методи криміналістики як виду практичної діяльності. Можемо скористатись загальновідомою їх класифікацією і зазначити, наприклад, що серед базових (домінуючих) можна розглядати методи експерименту - під час проведення такої слідчої (розшукової) дії, як слідчий експеримент (ст. 240 КПК України); метод ідентифікації у проведенні пред'явлення для впізнання (ст.ст. 228-230 КПК України) тощо.

Допоміжне (підпорядковане) становище у слідчій (адвокатській) діяльності, наприклад, можуть займати такі методи, як вимірювання або моделювання (зокрема, у формі створення зліпків) у процесі проведення огляду місця (оскільки базовими для цієї слідчої (розшукової) дії будуть методи спостереження та опису) тощо. Водночас необхідно зробити застереження про відносну нестабільність елементів тієї чи іншої групи методів у межах цієї класифікації, оскільки один і той же метод може набувати ознак як допоміжного, так і базового залежно від слідчої дії, у проведенні якої він застосовується.

За функціональним призначенням методи слідчої (адвокатської) діяльності можуть бути поділені на методи, що забезпечують: а) організаційну діяльність (методи криміналістичного версіювання, криміналістичного планування, криміналістичного аналізу ситуації); б) отримання доказової інформації у межах конкретних слідчих (розшукових) дій (методи спостереження, вимірювання, криміналістичної ідентифікації тощо); в) фіксування доказової інформації (методи опису; спеціальні криміналістичні методи, зокрема методи судової фотографії тощо). 
Стосовно особливостей криміналістичної діяльності головних учасників кримінального провадження як елемента аналізованого аспекту криміналістичної характеристики необхідно зазначити те, що ця діяльність $€$ невід'ємною частиною цього провадження. I саме завдяки їй у загальному плані здійснюється процес утілення права, а з ним - і втілення соціальної справедливості. Основним у цій діяльності (а в аналізованому контексті вона, зокрема, є криміналістичною) є розслідування злочинів, прокурорський нагляд за додержанням законності цього процесу та професійний захист.

Наступним чинником криміналістичної діяльності слідчого, прокурора чи адвоката - захисника $€$ те, що вона передбачає наявність у кожного 3 них відповідних владних чи інших службових повноважень, що гарантовані державою і здійснюються від імені чи під захистом держави. Характеризується ця діяльність високим рівнем відповідальності, а також надмірним рівнем емоційної напруженості. Крім цього, слідчій і прокурорській діяльності характерний також елемент примусу, який необхідний для подолання протидії з боку незаінтересованих у встановленні об’єктивної істини осіб.

Криміналістична (слідча, прокурорська та адвокатська) діяльність, виходячи із специфіки об'єкта свого впливу, також обов'язково передбачає наявність елементів творчості у ході пошуку об'єктивної істини. На цій підставі можна констатувати, що криміналістична діяльність головних дійових осіб досудового розслідування становить специфічний вид соціальної практики, який полягає у пізнанні подій протиправного характеру за допомогою відповідних закону прийомів та засобів.

I на завершення про останній елемент криміналістичної характеристики - недоліки слідства та професійного захисту (помилки та прогалини), причини, що їх породжують, та умови, що цьому сприяють.

Помилки слідства та професійного захисту - це недоліки, допущені слідчим (прокурором) та адвокатом - захисником під час застосування ними кримінального, кримінального процесуального чи іншого законодавства, незастосування або неправильне, неповне тощо застосування криміналістичних рекомендацій, які стали результатом добросовісного помиляння та призвели або можуть призвести до негативних наслідків.

Прогалини досудового розслідування і професійного захисту полягають у відсутності або недостатності фактичних зібраних даних, необхідних для всебічного й об’єктивного дослідження усіх обставин кримінального провадження з метою прийняття (ухвалення, постановлення) судом законного, обгрунтованого, вмотивованого і справедливого рішення.

Недоліки (помилки та прогалини) умисного характеру залежно від юридичних наслідків $є$ правопорушеннями, що зумовлюють настання адекватного виду юридичної відповідальності (аж до кримінальної). Хоча й помилки та прогалини необережного походження також мають своїм наслідком щонайменше дисциплінарну та матеріальну (як для слідчих і прокурорів регресну) відповідальність. 
Зрозуміло, що тут мова повинна йти про типові недоліки, які допускаються, зокрема, у формуванні доказової бази, а також про способи їх виявлення та локалізації у ході судового розгляду. Отже, найбільший інтерес для прокурора - обвинувача, адвоката - захисника і майбутнього головуючого судді становлять кримінальні процесуальні та кримінально-правові недоліки (помилки і прогалини). Вони мали б урахувати всі допущені під час досудового слідства порушення закону, оскільки згодом необхідно буде їх оцінити та диференціювати на такі, що є істотними або несуттєвими. Вiдомо й те, що порушення, узяті окремо, можуть визнаватися несуттєвими, а у своїй сукупності - виявитися істотними. Наявність порушень закону дає загальне уявлення про якість розслідування чи адвокатського захисту.

Особливого значення має набувати виявлення тих помилок, що стосуються дотримання прав підозрюваного у процесі досудового слідства. Серед них можуть бути помилки, пов'язані з неправильним застосуванням запобіжного заходу, неправильним відкриттям кримінального провадження, неправильним об'єднанням або виокремленням матеріалів досудового розслідування. Деякі 3 них можуть спричинити визнання судом усіх отриманих доказів недопустимими, відмову прокурора від обвинувачення i закриття кримінальної справи або виправдувальний вирок.

У ході підготовки до судового розгляду кримінальної справи можуть бути виявлені помилки, що спричинили порушення права підозрюваного на захист (проведення процесуальних дій без участі захисника, коли воно є обов'язковим унаслідок прямої вказівки в законі; відсутність перекладача, коли його участь у провадженні потрібна, тощо).

Деякі види помилок можуть бути усунені в результаті повернення обвинувального акту, клопотання про застосування примусових заходів медичного або виховного характеру прокурору, якщо вони не відповідають вимогам КПК України на момент проведення підготовчого провадження (п. 3 ч. 3 ст. 314 КПК України).

Враховуючи, що результат судового розгляду пов'язаний із дослідженням і оцінкою доказів, на особливу увагу заслуговує процедура збирання доказів, зокрема, в контексті оцінки відповідності закону порядку проведення слідчих (розшукових) дій, виявлення порушень, що можуть призвести до визнання отриманих доказів недопустимими.

Помилки, пов'язані 3 неповнотою або однобічністю проведеного розслідування, повинні бути цікавими, зокрема, з погляду достатності перевірки як версії обвинувачення, так і версії захисту. Необхідно встановити, чи були витребувані докази, що підтверджують позицію обвинуваченого, чи заявлялися клопотання в обгрунтування цієї позиції, чи відхилялися вони слідчим. Майбутні прокурор - обвинувач, адвокат та головуючий суддя мали б відзначити для себе переконливість одних доказів, слабкість інших, сумнівність третіх тощо. Так чи інакше всі вони групують докази, виокремлюючи обвинувальні і виправдувальні, твердо встановлені факти і сумнівні, законно отримані або отримані 3 порушенням процедури. 
Предмет судового розгляду (обставини, що підлягають встановленню судовим розглядом) є наступним елементом типової методики судового розгляду відповідної категорії кримінальної справи.

Будь-яка окрема чи групова методика повинна містити перелік обставин, що підлягають встановленню як на досудовій, так і на судовій стадіях кримінального провадження. Розглянемо докладніше предмет судового розгляду як обов'язковий елемент видової (групової) методики судового розгляду кримінальних справ.

Природно, що в основу цього переліку мають бути покладені обставини, зазначені у ст. 91 КПК України (це так звана кримінальна процесуальна характеристика відповідного кримінального правопорушення). Однак у кожній видовій чи груповій методиці судового розгляду цей єдиний перелік необхідно конкретизувати і розширити. По-перше, внаслідок потреби врахування основних і додаткових ознак того чи іншого виду чи групи злочинів і специфіки їх пізнання (а пізнання і доказування - поняття не тотожні) у формі розслідування та судового провадження (зокрема, через особливості аналізу й оцінки нової інформації, що надходить до відповідного учасника кримінального провадження на момент судового розгляду; через потребу враховувати характер ситуацій, що можуть виникнути, і тих, що реально складаються на різних етапах провадження у справі; через особливості можливих тактичних і правових рішень тощо).

По-друге, у судовому засіданні межі діяльності прокурора - обвинувача і адвоката - захисника стають дещо іншими, ніж для слідчого на досудовій стадії процесу. Адже в суді, як це передбачено ст.ст. 237-239 КПК України, може мати місце зміна меж судового провадження, зокрема зміна меж обвинувачення.

По-третє, предмет обвинувачення і захисту (поєднання предмета прокурорського й адвокатського доказування та пізнання), як видається, $є$ похідним не лише від меж судового розгляду, а й від тих завдань, які повинен вирішити прокурор - обвинувач і адвокат - захисник у ході здійснення, відповідно, функцій обвинувачення і захисту. На різних етапах здійснення функції обвинувачення і захисту ці завдання трансформуються і видозмінюються з урахуванням зміни процесуальних умов і завдань конкретної стадії процесу.

Такими загальними завданнями є: 1) зрозуміти (проаналізувати й оцінити) слідчу модель та модель захисту, тобто які з позиції слідчого (адвоката) обставини були інкриміновані обвинуваченому та, відповідно, взяті за основу захисту; 2) встановити, чи всебічно, повно й об’єктивно проведено розслідування (захист), чи правильно оцінено кожен доказ і всю їх сукупність, які щодо цього є прогалини і можливості їх усунення; 3) зробити попередні висновки про правильність застосування матеріального закону про кваліфікацію скоєного; 4) спланувати участь у судовому засіданні; оцінити результати слідства (захисту) з погляду їх допустимості і законності, наявності прогалин слідства (захисту), можливості і необхідності їх заповнення. 
Обізнаність із переліком обставин, що підлягають встановленню (доказуванню та пізнанню) у справах того чи іншого виду злочинів, даватиме змогу, по-перше, на етапі підготовки до судового розгляду оцінити докази, зібрані у процесі досудового розслідування, з погляду всебічності, повноти й неупередженості та оцінити, наскільки правильно визначено предмет і межі доказування; по-друге, скласти план дослідження доказів під час судового провадження, що буде об'єктом обговорення перед початком судового розгляду; по-третє, орієнтуватися безпосередньо за ходом дослідження тих чи інших доказів: показань, результатів експертних досліджень, документів тощо (зокрема, під час постановки запитань, заявлення, розгляду й вирішення клопотань тощо); по-четверте, визначити структуру і зміст своєї промови, яку прокурор (адвокат) виголошуватимуть на завершення судового розгляду.

Використання прокурором, адвокатом і судом тих чи інших тактичних і методичних рекомендацій стосовно реалізації ними відповідно до свого статусу функцій закономірно ситуативно зумовлено. Іншими словами, це залежить від характеру та наповнення перспективної або реальної криміналістичної (зокрема, судової) ситуації.

Судова ситуація (підвид криміналістичної ситуації) - це сукупність матеріальної та ідеальної інформації про умови, які, з одного боку, відображають досліджувану в суді подію, а з іншого - обстановку, за якої відбувається це дослідження і яка (ця інформація) екстраполюється на його завдання, а також шляхи та засоби їх реалізації, відповідно, судом, прокурором - обвинувачем, адвокатом - захисником.

Саме судова ситуація диктує кожному із цих трьох реалізаторів основних процесуальних функцій особливості проведення відповідних судових дій, зокрема, і методики судового розгляду загалом.

Тобто вона для кожного $з$ них зумовлює щонайменше три важливі блоки питань: 1) конструювання судових версій; 2) конкретизацію завдань судового провадження; 3) алгоритм дій на вирішення цих завдань.

На зміст судових ситуацій впливають, на нашу думку, ті ж чинники, що й на слідчу ситуацію: об’єктивні та суб'єктивні.

Об'єктивні чинники - це: 1) доказаність (обгрунтованість) обвинувачення; 2) наявність не тільки обвинувальних, а й виправдувальних обставин; 3) рівень та якість їх перевірки (спростування) тощо. Суб’єктивні - це: 1) очікувана протидія процесу встановлення істини з боку обвинуваченого (підсудного) чи інших зацікавлених осіб; 2) характер, кількість і зміст клопотань сторін, зокрема щодо спростування наявних та надання нових доказів тощо.

Судові ситуації поділяють на види за різними критеріями. Зокрема: 1) за елементним складом: а) прості (одноелементні); б) складні (багатоелементні або комплексні); 2) за співвідношенням інтересів учасників: а) проблемні (конфліктні); б) безпроблемні (безконфліктні); 3) за поширеністю: а) типові; б) нетипові (специфічні); 4) за характером конфлікту: а) особливо конфліктні (непримиренного суперництва); б) легкоконфліктні 
(незначного суперництва) [22, с. 123-125; 23, с. 89-90]; 5) за впливом на перебіг розгляду справи: а) сприятливі; б) несприятливі тощо.

Згідно з логікою і сутністю стадії судового провадження у першій інстанції як центральної та головної в контексті повноти реалізації принципів цього провадження стадії процесу можна, на нашу думку, припускати, що під час ііі реалізації суд має право виконати практично всі слідчі дії, так само як і під час досудового розслідування.

3 іншого боку, КПК України не передбачив можливості виконання у суді таких слідчих дій, як обшук та слідчий експеримент. Отже, відповідно до дії загального принципу діяльності будь-якого органу влади, а саме: дозволено те, що безпосередньо передбачено законом, випливає, що суд порівняно з досудовим розслідуванням дещо обмежений у можливостях доказування. Однак це не так, оскільки є ст. 333 КПК України, згідно з ч. 3 якої суд за клопотанням сторони кримінального провадження має право доручити органу досудового розслідування провести будь-які слідчі (розшукові) дії. У разі прийняття такого рішення суд відкладає судовий розгляд на строк, достатній для проведення слідчої (розшукової) дії та ознайомлення учасників судового провадження з ії результатами. Це, безумовно, дещо подовжує строк судового розгляду кримінальної справи, але не припиняє цей процес, не видозмінює його стадію тощо.

Отже, так чи інакше методика судового розгляду кримінальних справ повинна містити типові варіанти послідовності всіх ситуативно зумовлених судових, зокрема судово-слідчих, дій.

Ця послідовність залежить від: а) криміналістичної складності завершеного розслідування; б) особливостей виконуваних на досудовому розслідуванні слідчих (розшукових) дій щодо цієї категорії справ (убивства, крадіжки тощо); в) характеру можливих типових судових ситуацій на початок судового розгляду; г) типових результатів прогнозування змісту майбутнього судового провадження тощо.

Найповніше це прогнозування має здійснювати і реально здійснює прокурор - обвинувач. Зокрема, щодо: 1) поведінки учасників кримінального процесу; 2) можливої зміни доказової інформації; 3) результатів майбутніх судових, судово-слідчих дій; 4) складнощів майбутнього судового провадження тощо.

Методика судового розгляду повинна містити й тактичні особливості виконання, зокрема, судово-слідчих дій. Ці особливості розроблені криміналістикою для досудового розслідування злочинів. Їх і необхідно використати в судових засіданнях, але не шляхом механічного перенесення, а з урахуванням особливостей судового провадження та участі в ньому прокурора - обвинувача, адвоката - захисника, суду. Крім цього, необхідно напрацьовувати й нові тактичні положення, безпосередньо придатні в застосування у ході судового розгляду кримінальних справ.

Відомо, що судові дебати - це самостійний етап судового розгляду. Дебати включають виступи (промови) і репліки їхніх основних учасників.

Виокремлюють три основні аспекти судової промови, зокрема, прокурора та адвоката, які безпосередньо зумовлюють не лише ії зміст, а й такти- 
ку, тобто спосіб і прийоми ії побудови та виголошення: 1) психологічний аспект; 2) етичний; 3) логічний.

Діяльність прокурора й адвоката в судових дебатах - це акт, передусім, психологічний. Вона (ця діяльність) відбувається відповідно до своїх закономірностей і психологічної організації діяльності прокурора й адвоката у суді. За своєю психологічною природою їхній виступ у дебатах - це форма їх мовленнєвого спілкування з іншими учасниками судового провадження, спосіб передачі інформації. Це засіб їх переконання прокурором чи адвокатом у правильності висловлених ними тез і обгрунтованості запропонованих ними рішень.

Змістом судової промови завжди $є$ певні думки, ідеї, доводи, міркування, пропозиції. Вони неминуче пов'язуються з особистим ставленням прокурора та адвоката до результатів дослідження, їхнім емоційним сприйняттям інформації, психологічним станом переконаності у правильності зроблених ними висновків.

У психологічній структурі судових дебатів виокремлюють такі компоненти: а) психологічні властивості та якості виступаючого; б) психологія сприйняття промови і іï впливу на формування судового переконання.

Уважно вислуховуючи промови, зокрема прокурора та адвоката, судді подумки простежують пройдений шлях шукання істини, усвідомлюють і зіставляють доводи й аргументи обвинувача і захисника, порівнюють їх. Це дозволяє їм побачити сильні і слабкі сторони в аргументації учасників судових дебатів, внести свої корективи в їх оцінку, зробити правильні висновки, прийняти законне й обгрунтоване рішення.

Важливе місце у системі чинників, що впливають на тактику судової промови прокурора та адвоката, посідає етичний аспект. Професійна діяльність цих ключових учасників судового провадження завжди повинна здійснюватися на основі тих етичних принципів, які сформувались у суспільстві. Більше того, сама прокурорська й адвокатська діяльність виробляють свої норми професійної етики.

Дотримання прокурором (адвокатом) етичних норм сприяє повнішому, результативнішому виконанню ними своїх обов'язків, підвищенню ефективності їньої діяльності. Етичні засади вимагають від них індивідуального підходу до справи, яка розглядається, урахування особливостей учасників, які беруть участь у ній. Недопустимі приниження людської гідності, упередженість, однобокість у висвітленні обставин справи.

Прокурор і адвокат не мають права застосовувати незаконні засоби і методи для відстоювання своєї позиції, наполягати на твердженнях, які не підкріплені матеріалами справи. Вони не мають також права навмисно затягувати судовий розгляд справи, свідомо вводити суд і осіб, які присутні в залі судового засідання, в оману. Лише моральні засади здатні забезпечити прокурору та адвокату досягнення поставленої мети.

Логічний аспект $є$ тією базою, яка визначає обгрунтованість, переконливість і доказовість судової промови прокурора. Знання законів логіки, їх дотримання вважається необхідною умовою для правильного мислення, ви- 
словлювання своїх думок. В умовах судочинства, де на основі доказів формуються певні висновки і приймаються у справі відповідні рішення, знання законів логіки набуває для прокурора та адвоката особливого значення.

Закони логіки вимагають точного визначення тез, які доказуються. Усяка невизначеність, розпливчастість предмета обговорення неминуче вПлине на невизначеність висновків прокурора й адвоката. Вимоги логіки сприяють формуванню у них чітких суджень і обгрунтуванню їх доказами.

У тактичній структурі судових дебатів виокремлюють такі функції судової промови, зокрема прокурора й адвоката, як комунікативну та інформативну.

Судові дебати є здебільшого засобом спілкування, комунікації, способом обміну думками і судженнями. Це форма відстоювання судовими промовцями (т.зв. риторами) своїх процесуальних позицій, процес взаємодії між ними. У цьому розумінні судові промови - це засіб комунікативного зв’язку, спосіб реалізації комунікативної функції.

Судові промови виконують також інформативну функцію. Промова у судових дебатах повинна містити не лише відомості про досліджувані події, а й дані, які підтверджують правильність тлумачення цих подій. Обгрунтованість висновків і пропозицій у промові повинна бути аргументованою, доказовою, переконливою.

Висновки. Прокурор і адвокат як судові ритори відповідно до своєю процесуальної позиції аналізують і дають оцінку зібраним доказам, формулюють свої висновки й обгрунтовують їх тими відомостями, які були здобуті у процесі розслідування і судового розгляду справи.

Прокурор i, на наше переконання, адвокат зобов'язані у промові старанно і ретельно аналізувати не лише ті докази, які підтверджують їхню позицію, а й інформацію, що не узгоджується з нею. Цим самим забезпечується усебічність, повнота і неупередженість їхнього дослідження. Висновки, зроблені ними, стають переконливими й обгрунтованими, а якраз цього і чекають від них судді та інші учасники судового провадження.

\section{Література}

1. Бахин В.П. Предмет криминалистики : [лекция] / В.П. Бахин. - К., 1999. - 22 с.

2. Белкин Р.С. Криминалистика: проблемы, тенденции, перспективы. Общая и частная теории. Т. 1 / Р.С. Белкин. - М. : Юрид. лит-ра, 1987. - 272 с.

3. Белкин Р.С. Совершенствование предмета криминалистики в свете современных исследований / Р.С. Белкин / / Предмет и система криминалистики в свете современных исследований. - М., 1988.- С. 24-32.

4. Васильев А.Н. Предмет, система и теоретические основы криминалистики / А.Н. Васильев, Н.П. Яблоков. - М. : Изд-во Моск. ун-та, 1984. - 143 с.

5. Возгрин И.А. Научные основы криминалистической методики расследования преступлений. Ч. 1. / И.А. Возгрин. - СПб. : ЮИ МВД России, 1992. - 100 с.

6. Гончаренко В.Г. Методологічні проблеми вчення про предмет криміналістики / В.Г. Гончаренко / / Актуальні проблеми криміналістики : матер. Міжнар. наук.-практ. конфер. (м. Харків, 25-26 верес. 2003 р.). - Харків : Грифон, 2003. - С. 12-13.

7. Криміналістика. Криміналістична практика і методика розслідування злочинів / [В.О. Коновалова та ін.] ; ред. В.Ю. Шепітько ; Нац. юрид. акад. України ім. Ярослава Мудрого ; Акад. прав. наук України. - Харків : Право, 1998. - 375 с.

8. Волобуев А.Ф. Концепция Р.С. Белкина о предмете криминалистики и ее влияние на систему науки / А.Ф. Волобуев / / Роль и значение деятельности Р.С. Белкина в становлении 
современной криминалистики : матер. Междунар. науч. конфер. (к 80-летию со дня рождения Р.С. Белкина). - М. : Акад. управ. МВД РФ, 2002. - С. 91-95.

9. Гавло В.К. О предмете криминалистики и сфере приложения ее научного потенциала / B.К. Гавло / / Актуальные проблемы уголовного процесса и криминалистики на современном этапе. - Одесса, 1993. - С. 112-113.

10. Герасимов И.Ф. О перспективах развития и структуре криминалистики / И.Ф. Герасимов / / Перспективы развития криминалистики. - Свердловск, 1991. - С. 12-21.

11. Голунский С.А. Криминалистика: методика расследования отдельных видов преступлений / С.А. Голунский, Б.М. Шавер ; Ин-т права АН СССР ; под ред. А.Я. Вышинского. - М. : Юрид. изд-во НКЮ СССР, 1939. - 372 с.

12. Журавель В.А. Криміналістичні методики: сучасні наукові концепції : [монографія] / В.А. Журавель. - Харків : Апостіль, 2012. - 304 с.

13. Іщенко А.В. Методологічні проблеми криміналістики : [монографія] / А.В. Іщенко. К. : НВТ Правник ; НАВСУ, 1997. - 98 с.

14. Корж В.П. Теоретические основы методики расследования преступлений, совершаемых организованными преступными образованиями в сфере экономической деятельности : [монография] / В.П. Корж. - Харьков : Изд-во Нац. ун-та внутр. дел, 2002. - 412 с.

15. Корж В.П. Проблеми удосконалення системи сучасної криміналістики / В.П. Корж / / Вісник Академії адвокатури України. - 2012. - Ч. 1 (23). - С. 179-183. - [Електронний ресурс]. - Режим доступу : http:// aau.edu.ua/ua/visnyk23/\#sthash. P6DRKTV3.dpuf.

16. Матусовский Г.А. О пределах использования данных криминалистики / Г.А. Матусовский / / Проблемы социалистической законности на современном этапе развития советского государства : тезисы докладов межвуз. конфер. - Харьков, 1968. - С. 261-263.

17. Тіщенко В.В. Теоретичні і практичні основи методики розслідування злочинів : [монографія] / В.В. Тіщенко ; Одеська нац. юрид. акад. - Одеса : Фенікс, 2007. - 260 с.

18. Щур Б.В. Теоретичні основи формування та застосування криміналістичних методик : [монографія] / Б.В. Щур. - Харків : Харків юрид., 2010. - 320 с.

19. Когутич I.I. Криміналістичні знання, ї сутність і потреба розширення меж використання : [монографія] / I.I. Когутич. - Львів : Тріада Плюс, 2008. - 420 с.

20. Когутич I.I. Використання знань та засобів криміналістичної тактики і методики під час розгляду кримінальних справ у суді : [монографія] / I.I. Когутич. - Львів : Тріада Плюс, 2009. - 436 с

21. Когутич И.И. Отдельные аспекты развития криминалистической методики / И.И. Когутич / / Криминалистика и судебная экспертиза: наука, обучение, практика. - Вильнюс : Изд-во ун-та им. Миколаса Ромериса, 2007. - С. 60-66.

22. Питерцев С.К. Тактика допроса / С.К. Питерцев, А.А. Степанов. - СПб. : Питер, 2001. $-160 \mathrm{c}$

23. Ульянов В.Г. Государственное обвинение в российском уголовном судопроизводстве / В.Г. Ульянов. - М. : Олма-Пресс, 2002. - 352 с.

\section{Анот а ція}

Когутич I. I. Сутність і структура окремих складників методики судового розгляду кримінальних справ. - Стаття.

У статті на підставі аналізу тенденцій криміналістичної науки наведено аргументи на користь тези про потребу розширення предмета і системи криміналістичної методики. Обгрунтовано пропозицію стосовно того, щоб криміналістична методика містила дві частини: методику розслідування злочинів і методику судового розгляду кримінальних справ. Запропоновано диференційовану систему методики судового розгляду кримінальних справ, а також типову структуру видової (групової) методики судового розгляду кримінальної справи. Охарактеризовано окремі елементи цієї методики.

Ключові слова: кримінальна справа, методика розслідування злочинів, методика судового розгляду кримінальних справ. 


\section{Анно т а ция}

Когутич И. И. Сущность и структура отдельных составляющих методики судебного разбирательства уголовных дел. - Статья.

В статье на основании анализа тенденций криминалистической науки приведены аргументы в пользу тезиса о потребности расширения предмета и системы криминалистической методики. Обосновано предложение относительно того, чтобы криминалистическая методика содержала две части: методику расследования преступлений и методику судебного разбирательства уголовных дел. Предложена дифференцированная система методики судебного разбирательства уголовных дел, а также типичная структура видовой (групповой) методики судебного разбирательства уголовного дела. Охарактеризованы отдельные элементы этой методики.

Ключевые слова: уголовное дело, методика расследования преступлений, методика судебного рассмотрения уголовных дел.

\section{S u m m a r y}

Kogutych I. I. Essense and structure of separate components of court hearing methodology on criminal cases. - Article.

The article contains arguments for the thesis on the need to expand the subject and system of the criminalistics methodology based on trend analysis of criminalistics science. Suggestion on the division of criminalistics methodology into two parts was proved: methodology of crimes investigation and methodology of court hearing on criminal cases. Differentiated system of court hearing methodology on criminal cases as well as typical structure of species (group) methodology of court hearing on criminal cases were suggested. Separate elements of the aforementioned methodology were characterized.

Key words: criminal case, crime investigation methods, methods of trial of criminal cases. 